Phosphorus Research Bulletin Vol. 30 (2015) pp. 030-034 Memorial Paper for the Encouragement Prize 2013

\title{
THE ROLE OF NIOBIUM IONS IN CALCIUM PHOSPHATE INVERT GLASSES FOR BONE REGENERATION
}

\author{
Akiko Obata $^{1 *}$, Hirotaka Maeda $^{1}$, Kyosuke Ueda $^{2}$, \\ Takayuki Narushima $^{2}$, Toshihiro Kasuga ${ }^{1}$ \\ (*Corresponding author: obata.akiko@nitech.ac.jp) \\ ${ }^{1}$ Graduate School of Engineering, Nagoya Institute of Technology, \\ Gokiso-cho, Showa-ku, Nagoya, 466-8555 Japan \\ ${ }^{2}$ Graduate School of Engineering, Tohoku University, \\ 6-6-02 Aza Aoba, Aramaki, Aoba-ku, Sendai, 980-8579 Japan.
}

Keywords: Niobium ions, Calcium phosphate glasses, Osteoblast-like cells, Bioactivity

Abstract: Phosphate invert glasses (PIGs) containing niobium were prepared by a conventional melt-quenching method and the structures and chemical durability of the glasses and osteoblast-like cell responses to them were examined. Raman and solid state ${ }^{31} \mathrm{P}$ NMR spectra of the glasses demonstrated that two types of niobate groups, $\mathrm{NbO}_{4}$ and $\mathrm{NbO}_{6}$ units, were contained in the glasses and prepared to combine to pyrophosphate structure than orthophosphate one. The chemical durability in Tris- $\mathrm{HCl}$ solution was increased with the increase in the niobium content in the glasses, since niobium replaced to phosphorus and contributed to the formation of $\mathrm{P}-\mathrm{O}-\mathrm{Nb}$ and $\mathrm{Nb}-\mathrm{O}-\mathrm{Nb}$ bonds, which are stronger than $\mathrm{P}-\mathrm{O}-\mathrm{P}$ bond. The niobium ions released from the glasses enhanced the differentiation and mineralization of the cells, rather than the initial adhesion and proliferation. The upregulation of these cell functions by the niobium ions possessed doze-dependence; the medium containing $1 \times 10^{-7} \mathrm{M}$ of the ions exhibited the highest levels of the cell functions.

(Received Jan. 29, 2016; Accepted Feb. 27, 2016)

\section{INTRODUCTION}

Since 45S5-type bioactive glass (Bioglass ${ }^{\circledR}$ ) was developed for the use in medical and dental fields, many types of bioactive glasses have been developed. Most of them has silicate or phosphate systems. They have been applied to bone fillers, tooth fracture treatment, bone tissue engineering scaffolds and bioactive coatings for bioinert metallic materials. ${ }^{1-8}$ Recently, several kinds of inorganic ions released from bioactive glasses, such as calcium, phosphate, silicate, magnesium, zinc etc, have been reported to influence osteogenic cell functions. ${ }^{9}$ In particular, a trace amount of silicate ions enhance proliferation, differentiation and mineralization of osteoblasts. Xynos et al. found that insulin-like growth factor type II (IGF-II) of human osteoblasts was upregulated when $16.6 \mu \mathrm{g} / \mathrm{ml}$ of $\mathrm{Si}$ and $88.35 \mu \mathrm{g} / \mathrm{ml}$ of Ca were provided from 45S5-type bioactive glass, which enhanced the proliferation of the cells. ${ }^{10}$ Thus, to provide the ability of releasing such ions to biomaterials is one of the effective approaches for achievement of rapid bone regeneration in body. In particular, it must be useful for developing bioactive glasses with high performance, because most of glasses offer flexibility in the chemical components comprising the glasses.
Phosphate invert glasses (PIGs) are soluble and possess a neutral $\mathrm{pH}$ in aqueous solutions. Kasuga et al. developed PIGs with $60 \mathrm{CaO}-30 \mathrm{P}_{2} \mathrm{O}_{5}-7 \mathrm{Na}_{2} \mathrm{O}-$ $3 \mathrm{TiO}_{2}$ system (PIG-3Ti) and revealed its bioactivity of PIG-3Ti with in vivo and in vitro tests. ${ }^{11-15}$ The PIG-3Ti coating layer on a titanium alloy was covered with a new bone tissue in 4 weeks after implantation in a Japanese rabbit. To improve the bioactivity of PIGs, we have focused on doping of niobium ions into the glass system. Niobium ions have been reported to replace phosphorus ions in phosphate glasses and form O-P-O-Nb-O type chains. ${ }^{16,17}$ Additionally, the ions enhanced human osteoblast functions. ${ }^{18}$ Thus, we expected that niobium ions are able to be present homogenously in PIGs systems, which achieves a continuous release of niobium ions in aqueous solutions in association with dissolution of the glasses and rapid bone tissue regeneration.

In this short review, we provide an overview on the role of niobium ions in PIGs and mouse osteoblast-like cell reactions to the glasses. ${ }^{19,20}$ The cell tests were carried out using plates of the niobium-containing PIGs and also cell culture media containing their extracts, changing the contents of niobium in the glass systems and the culture media. Doze-dependences of upregulation of the cell 
functions by the niobium in or released from the glasses were examined.

\section{MATERIALS AND METHODS}

\section{1) Glass preparation}

PIGs containing $3-10$ mol\% of $\mathrm{Nb}_{2} \mathrm{O}_{5}$ were prepared by a conventional melt-quenching method. The nominal compositions of the glasses are shown in Table 1. $\mathrm{CaCO}_{3}, \mathrm{H}_{3} \mathrm{PO}_{4}, \mathrm{Na}_{2} \mathrm{CO}_{3}, \mathrm{Nb}_{2} \mathrm{O}_{5}$ and $\mathrm{TiO}_{2}$ (only for the glass as a control material) were used as the precursors. Mixed precursors were melted in an electric furnace at $1400{ }^{\circ} \mathrm{C}$ for $0.5 \mathrm{hr}$.

TABLE 1. Nominal compositions of glasses

\begin{tabular}{l|c|c|c|c|c}
\hline code & $\mathrm{CaO}$ & $\mathrm{P}_{2} \mathrm{O}_{5}$ & $\mathrm{Na}_{2} \mathrm{O}$ & $\mathrm{Nb}_{2} \mathrm{O}_{5}$ & $\mathrm{TiO}_{2}$ \\
\hline $\mathrm{PIG}-3 \mathrm{Nb}$ & 60 & 30 & 7 & 3 & 0 \\
\hline $\mathrm{PIG}-5 \mathrm{Nb}$ & 60 & 30 & 5 & 5 & 0 \\
\hline $\mathrm{PIG}-7 \mathrm{Nb}$ & 60 & 30 & 3 & 7 & 0 \\
\hline PIG-10Nb & 60 & 30 & 0 & 10 & 0 \\
\hline PIG-10Na & 60 & 30 & 10 & 0 & 0 \\
\hline PIG-3Ti & 60 & 30 & 7 & 0 & 3 \\
\hline
\end{tabular}

\section{2) Characterisation}

The structures of the prepared glasses were examined with Raman spectrometer and a magic-angle-spinning nuclear magnetic resonance spectrometer (MAS-NMR), especially the changes in the structure with the changes in the $\mathrm{Nb}_{2} \mathrm{O}_{5}$ contents.

For ion release measurements, powders with $<50 \mu \mathrm{m}$ in size of each glass were prepared and soaked in Tris- $\mathrm{HCl}$ buffer solution with $\mathrm{pH}=7.4$ and cell culture medium, minimum essential medium alpha serum containing $10 \%$ fetal bovine serum. Then the samples were incubation at $37{ }^{\circ} \mathrm{C}$ in air for the Tris-HCl buffer solution system and in a humidified atmosphere of $95 \%$ air and $5 \% \mathrm{CO}_{2}$ for the cell culture medium system, respectively.

The $\mathrm{pH}$ value of the cell culture medium after the incubation was measured to know if the glass dissolution induces changes in the $\mathrm{pH}$. Hydrophilicity of the glasses were measured using plates of each glass after polishing with sandpaper and mirror finish.

3) Cell culture tests
Cell culture tests were carried out for both the glass plates and the medium containing the extract of powders of PIG-10Nb to examine cell responses on the glass surfaces and the ions released from the glasses, respectively. The glass plates with dimensions of $4 \times 4 \mathrm{~mm}$ were placed on 96-well plate and mouse osteoblast-like cells (MC3T3-E1 cell) were seeded on their surfaces. To prepare the medium containing the extract of PIG- $10 \mathrm{Nb}$, the powders of the glass were soaked in the cell culture medium, incubated for 5 days, and then removed. The resulting media were diluted in order to adjust the niobium ion concentration to $1 \times 10^{-8}$ to $1 \times 10^{-5}$ $\mathrm{M}$ (denoted by " $\mathrm{Nb} 10^{-8} \sim 10^{-5}$ "), followed by being used for the cell culture using MC3T3-E1 cells.

\section{RESULTS AND DISCUSSION}

Raman spectra of the glasses demonstrated that niobium (niobate) ions are present as $\mathrm{NbO}_{4}$ and $\mathrm{NbO}_{6}$ groups in the glasses containing $\mathrm{Nb}_{2} \mathrm{O}_{5}$, as shown in Fig.1. A peak around $850 \mathrm{~cm}^{-1}$ is assigned to the $\mathrm{NbO}_{4}$ tetrahedra. ${ }^{21}$ Two peaks around 630 and 890 $\mathrm{cm}^{-1}$ correspond to the $\mathrm{Nb}-\mathrm{O}$ vibrations of an $\mathrm{NbO}_{6}$ octahedron corner-linked in a three-dimensional network $\left(\mathrm{NbO}_{6} 3 \mathrm{D}\right)$ and a short $\mathrm{Nb}-\mathrm{O}$ bond in an $\mathrm{NbO}_{6}$ octahedron $\left(\mathrm{NbO}_{6}\right.$ isolated $)$, respectively. ${ }^{22,} 23$ A peak around $790 \mathrm{~cm}^{-1}$ on only spectra of the glass containing over $7 \mathrm{~mol} \%$ is also assigned to $\mathrm{NbO}_{6}$;

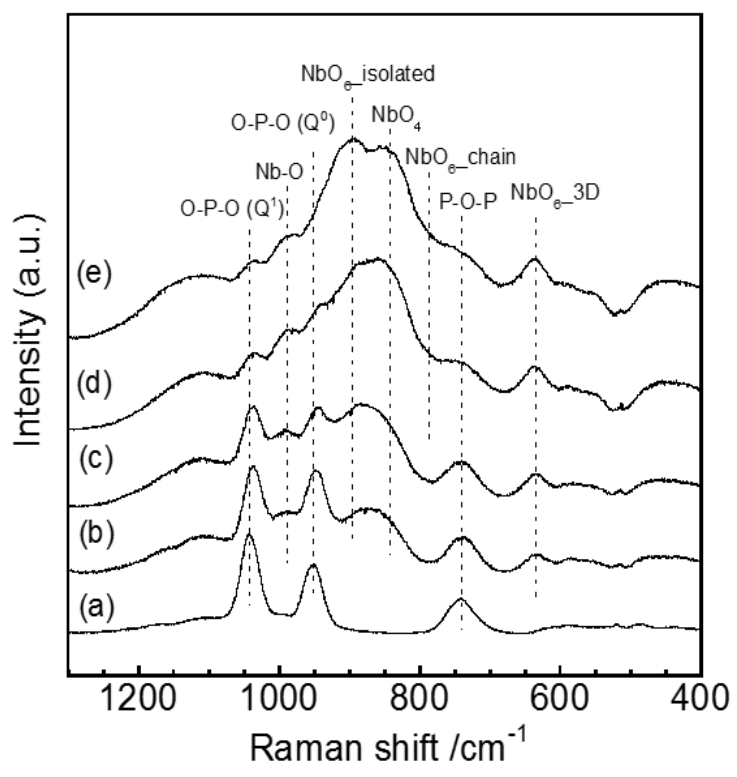

FIGURE 1. Raman spectra of the glasses. (a) PIG-10Na, (b) PIG-7Nb, (c) PIG-5Nb, (d) PIG-3Nb, and (e) PIG-10Nb. Reprinted with permission from reference 19 . 
(a)

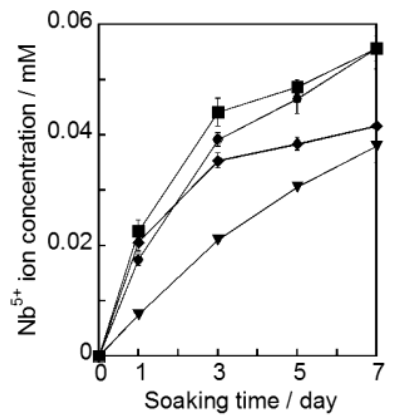

(b)

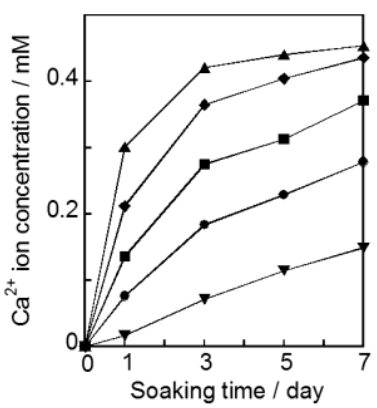

(c)

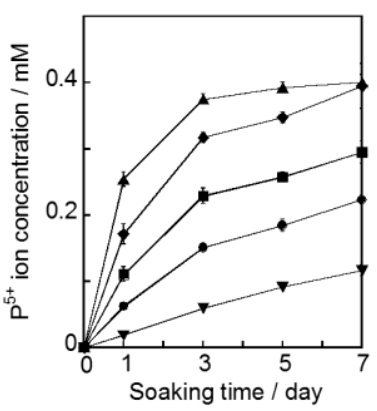

(d)

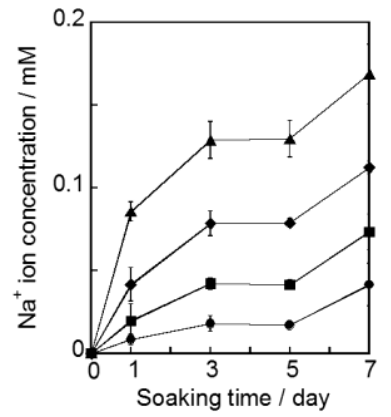

FIGURE 2. Concentrations of (a) $\mathrm{Nb}$, (b) $\mathrm{Ca}$, (c) $\mathrm{P}$, and (d) $\mathrm{Na}$ released from the glasses after soaking in

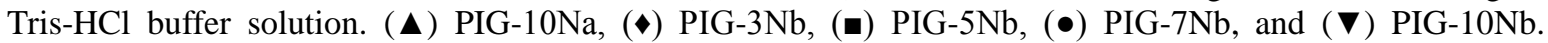
Reprinted with permission from reference 19.

this indicates the $\mathrm{NbO}_{6}$ octahedron linking into long chains $\left(\mathrm{NbO}_{6}\right.$ chain $){ }^{24}$ In addition, a peak around $980 \mathrm{~cm}^{-1}$, which appeared on the spectra of only the glasses containing $\mathrm{Nb}_{2} \mathrm{O}_{5}$, is suggested to correspond to $\mathrm{Nb}-\mathrm{O}$ bonding.

Regarding the peaks of phosphate groups, two peaks around 950 and $1040 \mathrm{~cm}^{-1}$ of $Q^{O}$ and $Q^{I}$ units in $\mathrm{O}-\mathrm{P}-\mathrm{O}$ bond were found to shift to the lower-energy side with adding $\mathrm{Nb}_{2} \mathrm{O}_{5}$ to the glasses. ${ }^{25,} 26$ This indicates that sodium ions interacting with $\mathrm{PO}_{2}$ groups were substituted by niobium ions. This was followed by the results of ${ }^{31} \mathrm{P}$ MAS-NMR. The peak position corresponding to $Q^{0}$ unit shifted to higher magnetic field with increasing the $\mathrm{Nb}_{2} \mathrm{O}_{5}$ content. This is because the electronegativity is 0.9 for sodium and 1.6 for niobium. The results of deconvolution for the Raman spectra with Gaussian functions followed by estimation of peak shift for each peak demonstrated that the portion of O-P-O of $Q^{0}$ unit increased with the increase in the $\mathrm{Nb}_{2} \mathrm{O}_{5}$ content, whereas that of P-O-P decreased. The portion of O-P-O of $Q^{l}$ unit kept a constant regardless of the $\mathrm{Nb}_{2} \mathrm{O}_{5}$ content.

On the other hand, for the peaks corresponding to $\mathrm{Nb}_{4} \mathrm{O}$ and $\mathrm{Nb}_{6} \mathrm{O}$, the portion of the peaks of $\mathrm{NbO}_{6}$ isolated unit to $\mathrm{Nb}-\mathrm{O}$ bonding decreased with the increase in the $\mathrm{Nb}_{2} \mathrm{O}_{5}$ content, whereas that of $\mathrm{NbO}_{4}$ tetrahedron bonding increased. The portions of the peaks of $\mathrm{NbO}_{6} 3 \mathrm{D}$ and $\mathrm{NbO}_{6}$ chain possessed almost no changes. Thus, the niobium ions in the glasses were supposed to form $\mathrm{NbO}_{4}$ as a glass network former, not $\mathrm{NbO}_{6}$ as a glass network modifier. This suggests that $\mathrm{P}-\mathrm{O}-\mathrm{Nb}$ bonds are formed in the glasses. In addition, the niobium species with different coordination numbers were found to prefer to combine to pyrophosphate structure than orthophosphate one from the results of ${ }^{31}$ P MAS-NMR.

The $\mathrm{P}-\mathrm{O}-\mathrm{Nb}$ bond formation was followed by the results of the immersion test using Tris- $\mathrm{HCl}$ solution. The ion amount released from the glasses decreased with the increase in the $\mathrm{Nb}_{2} \mathrm{O}_{5}$ content in the glasses (Fig. 2). This means $\mathrm{Nb}_{2} \mathrm{O}_{5}$ doping improved the chemical durability of the PIG system. This is because the $\mathrm{P}-\mathrm{O}-\mathrm{Nb}$ and $\mathrm{Nb}-\mathrm{O}-\mathrm{Nb}$ bonds are stronger than P-O-P bond. ${ }^{21}$

The ion release behaviour of the glasses in the cell culture media was different to that in Tris- $\mathrm{HCl}$ solution. Original culture medium (medium before immersing the glasses) contains several inorganic ions, including calcium, sodium and phosphate ions, proteins, amino acid, and so on. The differences in the components between the culture media and Tris- $\mathrm{HCl}$ buffer solution influenced the ion release behaviour of the glasses. The amounts of niobium and sodium ions released from the glasses increased with their contents in the glass system, whereas the amounts of phosphate and calcium ions eventually

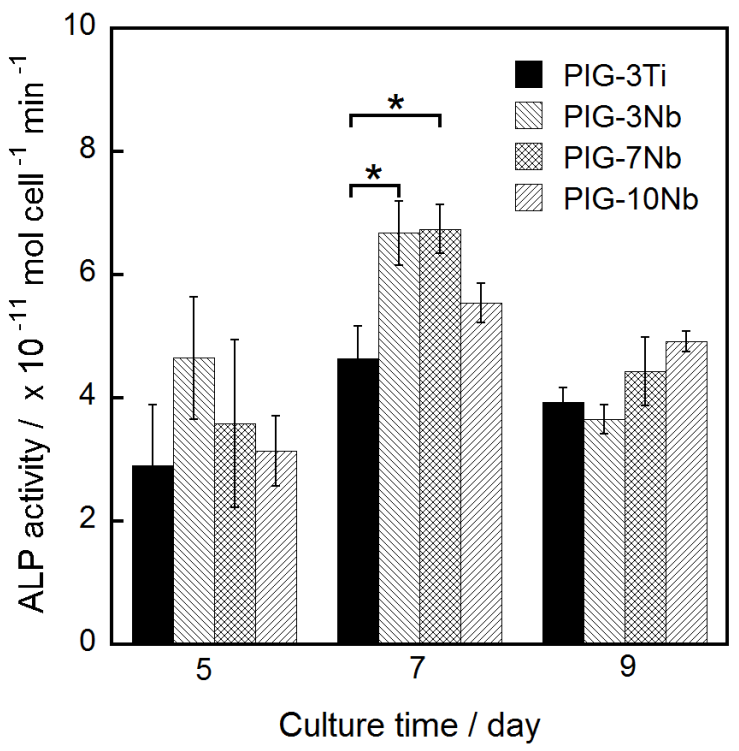

FIGURE 3. ALP activities in MC3T3-E1 cells cultured on the glass plates. Error bar means SD. $* p<0.05$. Reprinted with permission from reference 20 . 
reached almost similar levels after 7-d soaking. Niobium (niobate) ions released continuously from the glasses over the immersion period. This might means that the niobium ions are present homogenously in the glasses by replacing with phosphate ions in the glass structures.

The adhesion, proliferation, differentiation and mineralization of MC3T3-E1 cells cultured on the glass plate surfaces and in the media containing the extract of PIG-10Nb were examined. The niobium ions on the glass surfaces and in the media were found to enhance the differentiation and mineralization of the cells, rather than their adhesion or proliferation. In addition, the effects of the niobium ions on the cell functions possessed doze-dependence; only the cells cultured on the PIG-3Nb and $-7 \mathrm{Nb}$ surfaces showed upregulated differentiation ability (Fig. 3) and the medium containing $1 \times 10^{-7} \mathrm{M}$ exhibited higher activity of differentiation and mineralization than the other samples (Fig. 4). Effects of several kinds of inorganic ions, such as silicate and zinc ions, released from biomaterials on osteogenic cell functions also possess doze-dependence. ${ }^{27,}{ }^{28} \mathrm{Nb}$-containing media derived from $\mathrm{NbCl}_{5}$ with $>1 \times 10^{-5} \mathrm{M}$ niobium ions were reported to upregulate mineral deposition of normal human osteoblasts, whereas no upregulation was found for the media containing $1 \times 10^{-7}$ to $10^{-6} \mathrm{M}$ of the ions. ${ }^{18}$ In the results of this work, the medium containing only $1 \times 10^{-7} \mathrm{M}$ exhibited enhanced activity of differentiation and mineralization. The differences in the threshold for the upregulation between the two experiments are supposed to be due

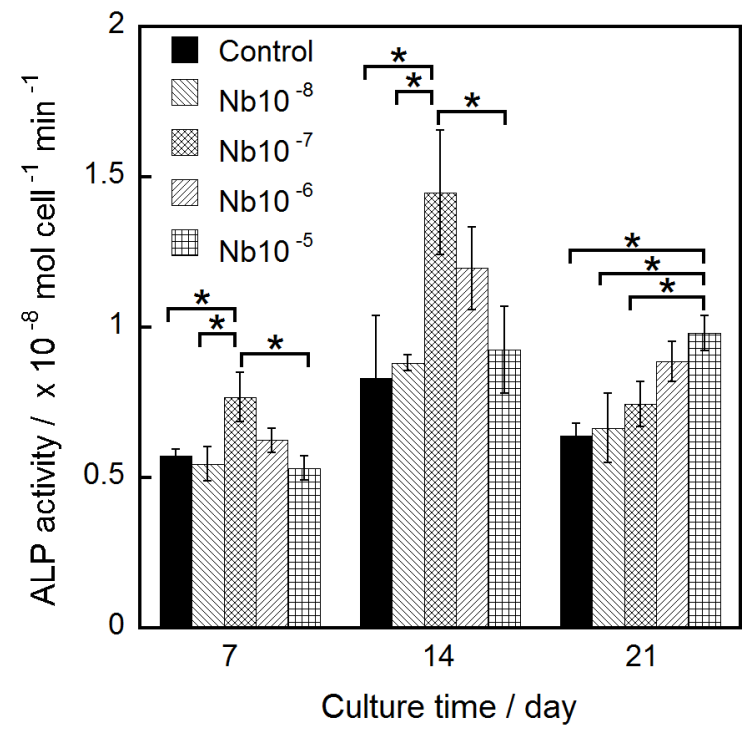

FIGURE 4. ALP activities in MC3T3-E1 cells cultured in the media containing niobium ions. Control means normal culture medium (containing no niobium ions). Error bar means SD. $* p<0.05$. Reprinted with permission from reference 20 . to the differences in cell types used for each test, because the effects of silicate ions on osteoblasts changed with the cell types. ${ }^{29}$ At any rate, the upregulation of the niobium ions in the glasses in the experiment of this work was also found to depend on the ion concentration.

Wettability of material surfaces and $\mathrm{pH}$ of the culture media after immersing materials are regarded to influence abilities of cells cultured on materials. These properties in this experiments were confirmed to be almost the same regardless of the glass components. Additionally, the initial adhesion and proliferation of MC3T3-E1 cells for 7 days got no influences by the changes in the glass components. Thus, the niobium ions in the glasses are regarded to influence only the differentiation and mineralization.

\section{SUMMARY}

Niobium doped in the calcium phosphate invert glasses influenced their chemical durability and the functions of osteoblast-like cells cultured on their surfaces, especially their differentiation and mineralization. The increase in the chemical durability of the glasses was due to the substitution of niobium for phosphorus and subsequent formation of $\mathrm{P}-\mathrm{O}-\mathrm{Nb}$ and $\mathrm{Nb}-\mathrm{O}-\mathrm{Nb}$ bonds, which are stronger than $\mathrm{P}-\mathrm{O}-\mathrm{P}$, in the glass structures. Two types of niobate groups, $\mathrm{NbO}_{4}$ and $\mathrm{NbO}_{6}$ units, were contained in the glasses and prepared to combine to pyrophosphate structure than orthophosphate one. All of the niobium-containing glasses released niobium ions constantly in both Tris- $\mathrm{HCl}$ solution and cell culture medium. The differentiation and mineralization of the cells were upregulated on the niobium-containing glasses than non-containing one, depending on the niobium content in the glass system. These upregulation was also found for the cells cultured in the media containing the extra of the glasses. This means the niobium ions released from the glasses stimulated the cells to differentiate and mineralize. Thus, the niobium-containing glasses are expected to exhibit excellent bone regeneration ability.

\section{ACKNOWLEDGEMENTS}

The present work was supported in part by KAKENHI Grant Number 25249094 and 26289238. The authors also would like to thank Mr. Tomohiro Miyajima, Mr. Yoshiaki Takahashi, and Mr. Sungho Lee for supporting the work.

\section{REFERENCE}


1. M.N. Rahaman, D.E. Day, B. Sonny Bal, Q. Fu, S.B. Jung, L.F. Bonewald, A.P. Tomsia, Acta Biomater. 7, 2355 (2011).

2. M. Vallet-Regí, C. Victoria Ragel, A.J. Salinas, Eur J Inorg Chem. 6, 1029 (2003).

3. L.L. Hench, J Am Ceram Soc. 81, 1705 (1998).

4. C.-P. Lin, F.-H. Lin, Y.-C. Tseng, S.-H. Kok, W.-H. Lan, J.-D. Liao, Biomaterials. 21, 637 (2000).

5. C.-P. Lin, Y.-C. Tseng, F.-H. Lin, J.-D. Liao, W.-H. Lan, Biomaterials. 22, 489 (2001).

6. L.L. Hench, I.D. Xynos, J.M. Polak, J Biomater Sci Polym Ed. 15, 543 (2004).

7. J.M. Gomez-Vega, E. Saiz, A.P. Tomsia, J Biomed Mater Res. 46, 549 (1999).

8. E. Saiz, M. Goldman, J.M. Gomez-Vega, A.P. Tomsia, G.W. Marshall, S.J. Marshall, Biomaterials. 23, 3749 (2002).

9. A. Hoppe, N.S. Güldal, A.R. Boccaccini, Biomaterials. 32, 2757 (2011).

10. I.D. Xynos, A.J. Edgar, L.D.K. Buttery, L.L. Hench, J.M. Polak, Biochem Biophys Res Commun. 276, 461 (2000).

11. T. Kasuga, M. Nogami, M. Niinomi, T. Hattori, Phosphor Res Bull. 17, 162 (2004).

12. T. Kasuga, Acta Biomater. 1, 55 (2005).

13. T. Kasuga, T. Mizuno, M. Watanabe, M. Nogami, M. Niinomi, Biomaterials. 22, 577 (2001).

14. T. Kasuga, M. Nogami, M. Niinomi, Adv Eng Mater. 5, 498 (2003).

15. T. Kasuga, T. Hattori, M. Niinomi, Phosphor Res Bull. 26, 8 (2012).

16. A. El Jazouli, J.C. Viala, C. Parent, G. Le Flem, P. Hagenmuller, J Solid State Chem. 73, 433 (1988).
17. F.F. Sene, J.R. Martinelli, L. Gomes, J Non-Cryst Solids. 348, 30 (2004).

18. M. Tamai, K. Isama, R. Nakaoka, T. Tsuchiya, $J$ Artif Organs. 10, 22 (2007).

19. H. Maeda, S. Lee, T. Miyajima, A. Obata, K. Ueda, T. Narushima, T. Kasuga, J Non-Cryst Solids. 432, Part A, 60 (2016).

20. A. Obata, Y. Takahashi, T. Miyajima, K. Ueda, T. Narushima, T. Kasuga, ACS Appl Mater Interfaces. 4, 5684 (2012).

21. S.M. Hsu, J.J. Wu, S.W. Yung, T.S. Chin, T. Zhang, Y.M. Lee, C.M. Chu, J.Y. Ding, J Non-Cryst Solids. 358, 14 (2012).

22. E.B. De Araujo, J.A.C. De Paiva, J.A. Freitas Jr, A.S.B. Sombra, J Phys Chem. 59, 689 (1998).

23. T. Cardinal, E. Fargin, G. Le Flem, S. Leboiteux, J Non-Cryst Solids. 222, 228 (1997).

24. A. Flambard, J.J. Videau, L. Delevoye, T. Cardinal, C. Labrugère, C.A. Rivero, M. Couzi, L. Montagne, J Non-Cryst Solids. 354, 3540 (2008).

25. A.E. Jazouli, C. Parent, J.M. Dance, G.L. Flem, P. Hagenmuller, J.C. Viala, J Solid State Chem. 74, 377 (1988).

26. R.K. Brow, D.R. Tallant, S.T. Myers, C.C. Phifer, J Non-Cryst Solids. 191, 45 (1995).

27. M.-Y. Shie, S.-J. Ding, H.-C. Chang, Acta Biomater. 7, 2604 (2011).

28. M. Ikeuchi, A. Ito, Y. Dohi, H. Ohgushi, H. Shimaoka, K. Yonemasu, T. Tateishi, J Biomed Mater Res. 67A, 1115 (2003).

29. I. Christodoulou, L.D.K. Buttery, P. Saravanapavan, G. Tai, L.L. Hench, J.M. Polak, J Biomed Mater Res Part B. 74, 529 (2005). 